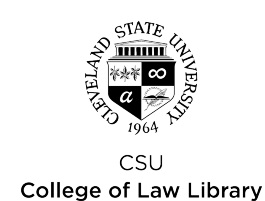

Cleveland State Law Review

Volume 68 | Issue 1

Article

$11-26-2019$

\title{
Grab the Fire Extinguisher Comparing UK Schemes of Arrangement to U.S. Corporate Bankruptcy after Jevic
}

David S. Stevenson

U.S. District Court, Northern District of Texas

Follow this and additional works at: https://engagedscholarship.csuohio.edu/clevstlrev

Part of the Bankruptcy Law Commons, Business Organizations Law Commons, Commercial Law Commons, and the Supreme Court of the United States Commons

How does access to this work benefit you? Let us know!

\section{Recommended Citation}

David S. Stevenson, Grab the Fire Extinguisher Comparing UK Schemes of Arrangement to U.S. Corporate Bankruptcy after Jevic, 68 Clev. St. L. Rev. 73 (2019) available at https://engagedscholarship.csuohio.edu/clevstlrev/vol68/iss1/7

This Article is brought to you for free and open access by the Journals at EngagedScholarship@CSU. It has been accepted for inclusion in Cleveland State Law Review by an authorized editor of EngagedScholarship@CSU. For more information, please contact library.es@csuohio.edu. 


\title{
GRAB THE FIRE EXTINGUISHER: COMPARING UK SCHEMES OF ARRANGEMENT TO U.S. CORPORATE BANKRUPTCY AFTER JEVIC
}

\author{
DAVID S. STEVENSON*
}

\begin{abstract}
Corporations overwhelmed with debt frequently turn to the courts for help to restructure their credit obligations, but some courts are more helpful than others. This is especially true when creditors cannot agree on a particular resolution, let alone when some creditors will not be paid at all. International corporations often have a choice of forum - and substantive insolvency law-based on their legal and physical presence in dozens or even hundreds of countries. The UK and U.S. offer different avenues for using insolvency law to restructure debts without total liquidation, and the American avenue has become more difficult to navigate thanks to the U.S. Supreme Court's decision in Czyzewski v. Jevic Holding Corp., 137 S. Ct. 973 (2017). In Jevic, the Court found that the Bankruptcy Code does not allow parties to dismiss a bankruptcy case through a "structured dismissal" to pay creditors in a manner that violates the Code's absolute priority rule. This decision weakens the ability of corporate debtors and their creditors to structure a pre-plan settlement that satisfies some, but not all, creditors. The Article starts with an overview of both insolvency systems and proceeds into a thorough comparison of features relevant to a corporation choosing between the two legal schemes. The Article concludes by suggesting that, while each system has advantages over the other, a distressed (but not yet doomed) corporation choosing between the forums should opt for a more flexible UK "scheme of arrangement" rather than a Chapter 11 filing in U.S. Bankruptcy Court.
\end{abstract}

\section{CONTENTS}

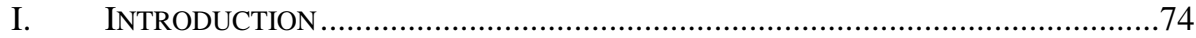

II. Why COMPANIES FILE: AN OVERVIEW OF U.S. CORPORATE BANKRUPTCY ...76

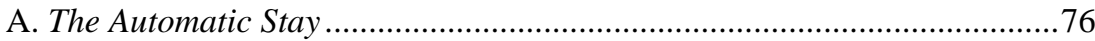

B. Chapter 11 Plans of Reorganization -The Basics ....................................78

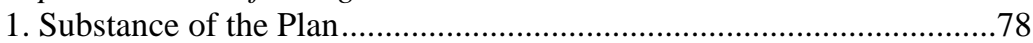

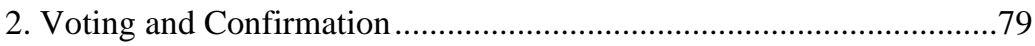

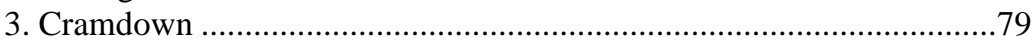

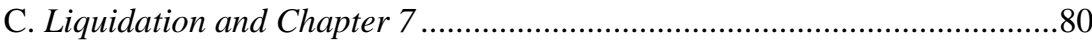

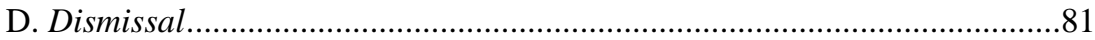

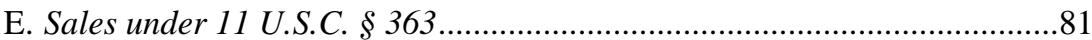

III. JEVIC: WHEN THE ABSOLUTE PRIORITY RULE APPLIES ......................................83

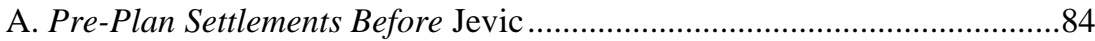

\footnotetext{
* J.D., with high honors, The University of Texas School of Law; B.S., Baylor University; Judicial Law Clerk to the Honorable D. Gordon Bryant, Jr. of the United States District Court, Northern District of Texas.
} 


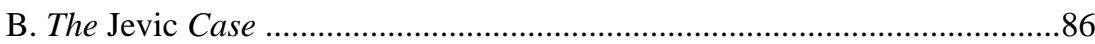

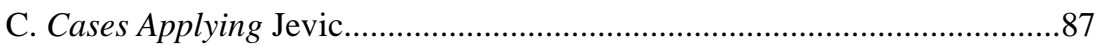

IV. THE United KINGDOM’S INSOLVENCY SYSTEM ….......................................87

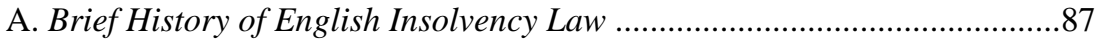

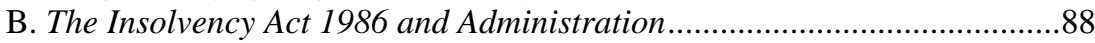

C. Company Voluntary Agreements.............................................................8

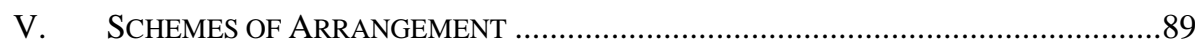

A. Scheme of Arrangement Procedure ………………..................................90 1. The Company Applies to the Court for an Order Summoning Meetings

.............91

2. Class Meetings and Voting .................................................................92

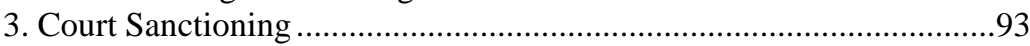

B. Substantive Requirements of a Scheme of Arrangement ...............................94

C. Using a Scheme of Arrangement to Sell the Company .................................94

D. Recognition of Schemes of Arrangement in Other Countries .....................95

VI. COMPARING SCHEMES OF ARRANGEMENT TO AMERICAN BANKRUPTCY AFTER

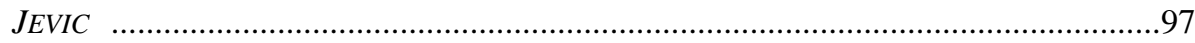

A. Substantive Provisions and the Power to Bind Nonconsenting Creditors .97

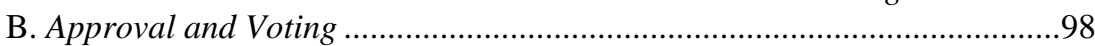

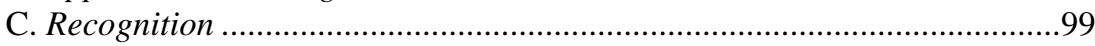

D. Anti-Enforcement Protection ...............................................................100

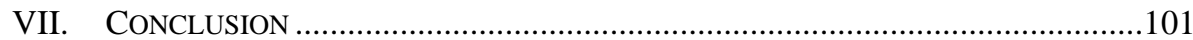

\section{INTRODUCTION}

The United States and the United Kingdom have similar bankruptcy systems, but the systems have an important procedural difference that affects a debtor's ability to approve a restructuring arrangement over the objection of creditors that disapprove of the arrangement. In the United States, a corporation looking to reorganize its debts over the objection of creditors, in a way that binds those creditors, must seek formal bankruptcy protection by filing a case under Chapter 11 of the Bankruptcy Code and then propose and confirm a plan that conforms to significant procedural and substantive requirements, including the absolute priority rule. In the United Kingdom, a procedure known as a "scheme of arrangement" allows corporations subject to the court's expansive jurisdiction under the Insolvency Act to avoid filing an insolvency case altogether and meet with creditors to discuss a plan. If a majority of creditors in each class of interests, accounting for $75 \%$ or more of each class's aggregate claims amount, approves the arrangement, then the English courts will certify the scheme and make it binding as to all creditors in those classes, even unknown creditors and nonconsenting creditors. This allows companies reorganizing in the United Kingdom more flexibility to bind nonconsenting creditors than the companies would have if they filed for bankruptcy protection in the United States.

The United States Supreme Court's recent decision in Czyzewski v. Jevic Holding 
Corp. ${ }^{1}$ makes this difference in flexibility more pronounced: the absolute priority rule governing American bankruptcy distributions applies to structured dismissals as well. In Jevic, the Supreme Court struck down a structured dismissal of a Chapter 11 case that provided for payment of some low-priority unsecured claims but did not provide for payment of high-priority wage claims of the defunct company's employees. ${ }^{2}$ In doing so, the Court emphasized the importance of the absolute priority rule, which requires that senior creditors be paid in full before junior creditors are paid at all, to the proper functioning of the Bankruptcy Code. ${ }^{3}$ Although it is unclear whether the Supreme Court's decision in Jevic extends the absolute priority rule to all distributions of estate property before confirmation of a plan, rather than only to structured dismissals and final dispositions of bankruptcy cases, bankruptcy courts applying Jevic have generally extended its holding to apply even to settlements and arrangements early in the case. This opinion therefore eliminates, or at least sharply curtails, the corporate debtor's ability to circumvent the absolute priority rule by proposing a settlement before the final disposition of a bankruptcy case. After Jevic, bankruptcy courts in America must apply a more rigid test to corporate debtors' arrangements, which widens the gap in flexibility between the American and U.K. systems. At least in theory, a corporate debtor seeking flexibility in their arrangement would be inclined, especially after the Jevic decision, to choose the more flexible procedures available in the United Kingdom.

Problematically, though, schemes of arrangement proposed without the filing of an insolvency case (so-called "solvent schemes of arrangement") may or may not be recognized overseas, which potentially limit their usefulness to international corporations seeking to enforce an arrangement worldwide. In particular, German courts have held, on different occasions, that the European Union's agreements about enforcing other country's judgments do not apply to certain English schemes of arrangement that purport to bind nonconsenting German claimants when no formal insolvency proceeding has been filed. ${ }^{4}$ Schemes of arrangement have been recognized in Spain and Singapore, but a Singapore court, recently deciding a scheme-ofarrangement case, disagreed with the Applicant's assignment of claimants to a single class and split the claims into two classes. ${ }^{5}$ The number and status of classes is very important to the proper function of a scheme of arrangement because each class involved in the scheme must approve the scheme by majority vote and the approval of

\footnotetext{
${ }^{1} 137$ S. Ct. 973 (2017).

${ }^{2}$ Id. at 978 .

${ }^{3}$ Id. at 983.

${ }^{4}$ Stefan Sax \& Cristina Weidner, Insolvency \& Restructuring - Germany, INT'L LAW OFFICE (Globe Business Media Group, London, U.K.), Aug. 3, 2012.

5 Corinne Ball, Singapore Court of Appeal Issues Landmark Ruling on Schemes of Arrangement in Reliance on Developments in Australia, the U.K. and Other Common Law

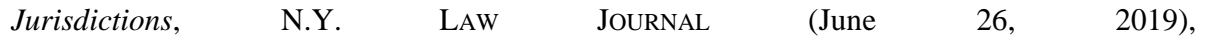
https://www.law.com/newyorklawjournal/2019/06/26/singapore-court-of-appeal-issueslandmark-ruling-on-schemes-of-arrangement-in-reliance-on-developments-in-australia-the-uk-and-other-common-law-jurisdictions/.
} 
at least $75 \%$ of the class's aggregate claim value. ${ }^{6}$ Consequently, a scheme of arrangement is binding on all creditors in a class, regardless of their approval and whether they were known at the time the scheme was approved. Because of the importance of the number and character of classes involved in a scheme of arrangement, the possibility that a foreign court will accept a scheme of arrangement but reorganize the classes involved could complicate or frustrate the purpose of the scheme.

This Article begins with a discussion of corporate bankruptcy and restructuring under the United States Bankruptcy Code, examining the provisions most relevant to a corporate debtor's decision to file for bankruptcy protection in the United States. This section introduces the notion of "cramdown," the process by which a plan can be approved over objections from classes of creditors, triggering certain protections for those creditors including application of the absolute priority rule to the plan in question. The next section discusses pre-plan settlements and the immediate effect of the Jevic decision on bankruptcy cases in the United States. Following that discussion, the Article briefly examines the English insolvency system, focusing particularly on schemes of arrangement. The Article then evaluates some of the strengths and weaknesses of schemes of arrangement in international insolvency, comparing them to the United States bankruptcy system on several points: power to bind nonconsenting creditors, approval and voting, recognition in other countries, and anti-enforcement protection. The Article concludes that English schemes of arrangement, because of their flexibility as non-insolvency procedures, can be used to prevent problems that formal bankruptcy can only fix retrospectively.

\section{Why COMPANIES FILE: AN OVERVIEW OF U.S. CORPORATE BANKRUPTCY}

Bankruptcy can be a powerful tool for a corporation looking to sell or reorganize. A corporation seeking bankruptcy protection in the United States typically files a case under Chapter 11 of the United States Bankruptcy Code. ${ }^{7}$ When the corporation files the case, the filing triggers the duties and protections of the Bankruptcy Code. ${ }^{8}$ Under section 521 of the Code, for instance, the debtor must file a list of creditors, schedule its assets and liabilities, disclose secured interests in its property, and make many other disclosures related to its financial condition. ${ }^{9}$ Also, all property of the corporate debtor at the time of filing a bankruptcy case becomes "property of the estate," to be managed by the trustee in bankruptcy or the debtor in possession for the benefit of the estate. ${ }^{10}$ The protections of the Bankruptcy Code make it particularly attractive for corporate debtors seeking a "fresh start" for their company or to maximize the value of its assets relative to its liabilities, regardless of whether the corporation wants to sell.

\section{A. The Automatic Stay}

Filing a bankruptcy case also triggers one of the most important Bankruptcy Code

\footnotetext{
${ }^{6} I d$.

711 U.S.C. $\$ \S 301,1101$ et seq. (2019).

${ }^{8}$ Id. $§ 521$.

${ }^{9} I d$.

${ }^{10} I d . \S 541$.
} 
protections: the automatic stay. ${ }^{11}$ The automatic stay is an injunction that prevents the debtor-in-bankruptcy's creditors from seeking collection on their claims, continuing lawsuits against the debtor in other courts, executing judgments on the debtor's property, and otherwise trying to obtain the debtor's property. ${ }^{12}$ The automatic stay operates as a broad protection for the debtor against the creditors closing in for whatever they can get, and it covers a wide range of activities, although criminal prosecution and certain domestic-relations actions-including paternity proceedings - are particular exceptions..$^{13}$

The automatic stay is important because it allows the corporate debtor to focus on reorganization of its assets and liabilities without worrying about competing creditors closing in. ${ }^{14}$ Without the injunctive force of the automatic stay, the corporate debtor's filing a bankruptcy case would be the beginning of the end. The filing of the case would alert the corporate debtor's creditors that it has insufficient funds to pay all its debts in full, and each creditor-operating in self-interest and knowing that not all creditors will receive payment on their claims - would get in line to be the first one paid. The creditors would have even more motivation to be aggressive in collection, seizing property and seeking liens as quickly as possible, which would have an adverse effect on the overall value of the corporate debtor's estate. As each creditor chips away at the corporate debtor's assets, none of them are focused on maximizing the value of the overall estate or "making the pie bigger"; they are primarily, if not solely, focused on making sure that they "get their slice of the pie" - that is, payment on the claims they hold in the corporate debtor's assets. The automatic stay prevents this tragedy of the commons by preventing all creditors from proceeding to collect on the corporate debtor's assets for the duration of the bankruptcy case, enabling the debtor to work together with its creditors to maximize the value of the bankruptcy estate and, thus, the amount of all creditors' total recovery on their claims. ${ }^{15}$

This protection is not without its exceptions, however. As mentioned above, this automatic stay does not stop or prevent criminal prosecutions. ${ }^{16}$ Additionally, creditors can seek relief from this injunction by motion to the bankruptcy court. ${ }^{17}$ Section 362(d)(1) allows a lifting of the automatic stay where the creditor's interest in certain property is not adequately protected, or otherwise "for cause."18 Section 362(d)(2) involves a more specific circumstance: for some particular property in which the creditor has an interest, the debtor has no equity in the property, and that "such

${ }^{11} I d . \S 362$.

${ }^{12} I d . \S 362(\mathrm{a})$.

${ }^{13} I d . \S 362(\mathrm{~b})(1)-(2)$.

14 Elizabeth Warren, Jay Lawrence Westbrook, Katherine Porter \& John A. E. Pottow, The Law of Debtors and Creditors: Texts, Cases, and Problems 67 (7th ed. 2014) [hereinafter Debtors and Creditors].

${ }^{15} I d$.

${ }^{16} 11$ U.S.C. $\$ 362(b)(1)$ (2019).

${ }^{17} I d . \S 362(\mathrm{~d})$.

${ }^{18} I d . \S 362(\mathrm{~d})(1)$. 
property is not necessary for an effective reorganization." ${ }^{19}$ Essentially, the bankruptcy court will lift the automatic stay if it finds that the corporate debtor lacks equity in the property and that it does not have a plan to use it to reorganize effectively.

The automatic stay, while broad in scope, has limitations in its applicability to foreign entities based on the United States' rules on jurisdiction. The language of the Bankruptcy Code creating the stay indicates that it is "applicable to all entities"- that is, any party anywhere in the world that may be interested in the case or the corporate debtor. ${ }^{20}$ But the bankruptcy court, as a court of the United States, only has the jurisdiction granted to it in the Constitution and the United States Code, and courts of the United States might not reach outside the country's borders to interfere in foreign affairs. ${ }^{21}$ Thus the automatic stay, while broad within the United States and as to entities with assets in the United States, is less powerful outside its own borders. As discussed infra, some countries "recognize" the bankruptcy cases of other countries' courts; the United States recognizes other countries' proceedings through Chapter 15 of the Bankruptcy Code. ${ }^{22}$

\section{B. Chapter 11 Plans of Reorganization-The Basics}

For many corporations filing a case under Chapter 11, the ultimate goal of the case is to propose, confirm, and carry out a plan of reorganization. Confirmation of a plan of reorganization vests the property of the estate back to the corporate debtor and discharges all pre-petition claims, liens on property, and interests against the debtor. ${ }^{23}$ A confirmed plan also binds not only those creditors who benefit from and accept the plan but also those that are "impaired" under the plan or vote against it. ${ }^{24}$ A plan of reorganization, if confirmed, allows the corporate debtor to move forward with its debts discharged and a plan binding as to its creditors, whether or not they are happy with the plan.

\section{Substance of the Plan}

Chapter 11 of the Bankruptcy Code specifies what provisions may-or must-be contained in a plan of reorganization. Section 1123(a) of the Code outlines the necessary provisions for a plan to be confirmed, including descriptions of each class of claims or interests, whether the classes are impaired, treatment of impaired classes or claims, and provision of adequate means for the plan to be implemented. ${ }^{25}$ Section 1123(b) includes provisions and actions that the plan may include: a plan can impair creditors or classes, provide for the sale of substantially all the debtor's assets, provide

${ }^{19} I d . \S 362(\mathrm{~d})(2)$.

${ }^{20} I d . \S 362(\mathrm{a})$.

${ }^{21}$ See 28 U.S.C. § 1334 (2019) (giving United States District Courts jurisdiction over bankruptcy matters, which is then delegated to bankruptcy courts); In re Union Carbide Corp. Gas Plant Disaster at Bhopal, India, 634 F. Supp. 842, 860 (S.D.N.Y. 1986), aff'd as modified, 809 F.2d 195 (2d Cir. 1987) (declining to hear a case on public and private grounds based on the case's grounding in, and connections to, India alone).

2211 U.S.C. $\S 1515$ et seq. (2019).

${ }^{23} I d . \S 1141$.

${ }^{24}$ Id. § 1141(a).

${ }^{25}$ Id. $\S 1123(\mathrm{a})$. 
for assumption or rejection of executory contracts, and "include any other appropriate provision not inconsistent with the applicable provisions of [the Bankruptcy Code]." ${ }^{26}$ A corporate debtor bringing a plan before the bankruptcy court has broad discretion as to the contents of the plan under $\S 1123(\mathrm{~b})$, which is another reason why plans of reorganization are so attractive to corporate debtors. Importantly, one of the available actions that a plan can incorporate is the sale of substantially all the debtor's assets: a corporation can use a Chapter 11 Plan to sell itself rather than reorganize, assuming the plan otherwise conforms to the Bankruptcy Code's requirements. ${ }^{27}$

\section{Voting and Confirmation}

While the corporate debtor has discretion to propose a plan and choose its contents, the plan must still be confirmed, which requires approval of at least some creditors. ${ }^{28}$ Impaired classes and creditors are of particular importance: for a plan to be confirmed, classes of creditors that are impaired - that is, their legal, equitable, or contractual rights are affected under the plan - generally must vote in favor of the plan or, if they do not, the plan must provide for the impaired class to receive more than it would under a Chapter 7 Liquidation (discussed in more detail infra). ${ }^{29}$ Classes and creditors that are not impaired are conclusively presumed to have accepted the plan, so seeking their approval of the plan is not necessary. ${ }^{30}$ The corporate debtor thus has discretion to impair classes or leave classes unimpaired under 1123(b), but that choice has consequences for the possible confirmation of its plan of reorganization.

\section{Cramdown}

Even if impaired classes do not vote in favor of a proposed plan of reorganization, the plan can still be confirmed via cramdown. "Cramdown" is an industry-shorthand term that itself is found nowhere in the Code, but it refers to the process of confirming a plan over the objection of impaired classes that nonetheless binds those impaired classes. ${ }^{31}$ For a cramdown to occur, at least one impaired class must still approve of the plan, and all other requirements under 1129(a) — except the requirement that each impaired class approve under 1129(a)(8) - must still be satisfied. ${ }^{32}$ This process implicates additional requirements under section 1129(b) of the Bankruptcy Code, including the requirement that the plan not discriminate unfairly against classes and that the plan be "fair and equitable." ${ }^{33}$ The latter requirement- that the plan be fair and equitable-incorporates an important function of the Bankruptcy Code: the absolute priority rule..$^{34}$

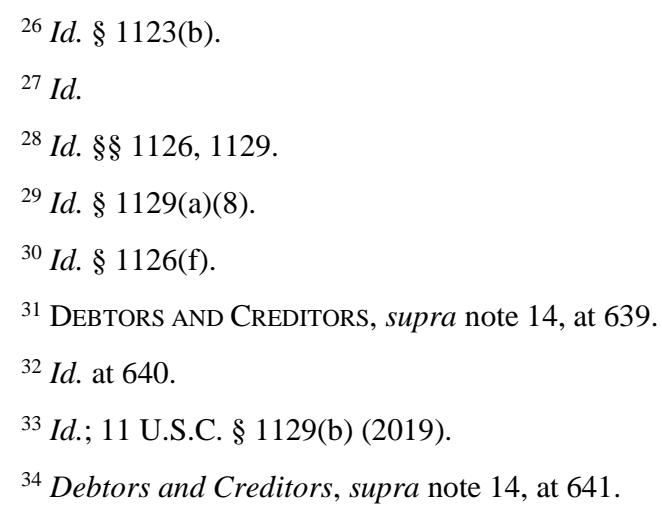


The absolute priority rule, as codified in section 1129(b)(2) of the Code, requires that each creditor, or class of creditors, be paid in full before lower-priority creditors or interest holders receive anything. ${ }^{35}$ The level of priority that each unsecured creditor has is set out in section 507(a) of the Code; any unsecured claim not listed in 507(a) is a general unsecured claim and is below all priority claims. ${ }^{36}$ For a reorganization plan to be "fair and equitable," it must provide for payment according to this rule: for each class of creditors, that class (assuming its members hold claims of the same level of priority) must be paid in full before lower-priority creditors are paid at all. ${ }^{37}$

Cramdown, examined in light of the general plan confirmation process, reveals several important considerations the Bankruptcy Code balances. Corporate debtors are encouraged to propose a plan of reorganization that contains an innovative solution to the company's financial problems, and they have broad discretion in deciding which terms to include and how to deal with their current obligations. To make the plan work, however, they must communicate with their creditors and make sure that any classes that would be impaired under the plan would still vote in favor of the plan. ${ }^{38}$ The corporate debtor cannot merely write off their creditors: if the impaired classes do not approve the plan, the plan will be subject to cramdown requirements, and it, therefore, must provide for the payment in full of every impaired class before any lower-priority classes receive anything on their claims. ${ }^{39}$ Even then, at least one impaired class must approve the plan. ${ }^{40}$ The corporate debtor needs to think carefully about the plan of reorganization it proposes, work with its creditors, and make sure the plan satisfies the Code's requirements.

\section{Liquidation and Chapter 7}

Not all Chapter 11 bankruptcy cases end with the confirmation of a plan. When no plan can be proposed or confirmed, a case filed under Chapter 11 may be converted to a Chapter 7 liquidation case or dismissed. ${ }^{41}$ Notably, a debtor in possession - that is, the corporate debtor acting as its own trustee in a Chapter 11 case-can convert the case to a Chapter 7 case at its own discretion if they filed for Chapter 11 bankruptcy voluntarily. ${ }^{42}$ The Chapter 11 case might also be converted involuntarily, on motion from a party in interest, for cause, although "cause" does not include delay or failure to propose a confirmable plan. ${ }^{43}$ A corporation can file for Chapter 7 bankruptcy in the first place, but Chapter 11 allows the company to remain in possession of the estate and gives more leeway with the administration of a plan.

\footnotetext{
${ }^{35}$ Id.; 11 U.S.C. $\$ 1129$ (b)(2)(B) (2019); PraCtICAL LAW BANKRUPTCY \& RESTRUCTURING and Practical Law Finance, Order of Distribution in Bankruptcy $§ 3$ (2019), Westlaw.

36 Practical Law Bankruptcy \& Restructuring and Practical Law Finance, Order OF DisTRIBUTION IN BANKRUPTCY $§ 3$ (2019), Westlaw.

3711 U.S.C. § 1129(b)(2) (2019).

${ }^{38}$ Debtors and Creditors, supra note 14, at 639.

${ }^{39} \mathrm{Id}$.

${ }^{40} I d$.

${ }^{41} 11$ U.S.C. $\$ 1112$ (2019).

${ }^{42}$ Id. $\S 1112(\mathrm{a})$.

${ }^{43}$ Id. $\S 1112$ (b).
} 
In a Chapter 7 liquidation, the automatic stay still applies, and the corporate debtor's duties to disclose assets and liabilities are the same. ${ }^{44}$ After filing for or conversion to Chapter 7, the United States Trustee appoints a neutral and disinterested trustee to administer the bankruptcy estate. ${ }^{45}$ Creditors may later elect a new trustee. ${ }^{46}$ The trustee then collects, liquidates, and distributes the property of the estate to creditors and interest holders according to the order set out in section 726 of the Code. ${ }^{47}$ The debtor is then discharged of its remaining debts. ${ }^{48}$

Importantly, the distribution scheme in section 726 of the Code incorporates the absolute priority rule as well: the first group to get paid in a liquidation is priority claims under 507(a) of the Code. ${ }^{49}$ In Chapter 7 cases and Chapter 11 cases converted to Chapter 7, the absolute priority rule is thus still in full force, and priority creditors will be paid in full before junior creditors receive anything on their claims.

\section{Dismissal}

Alternatively, a bankruptcy case can be dismissed. In the case of dismissal, creditors' prepetition claims are reinstated; any lawsuit or other action stayed by the automatic stay resumes in full force; certain bankruptcy court judgments are vacated; and all property is returned to whomever had possession of it immediately before filing. ${ }^{50} \mathrm{~A}$ dismissal is therefore a restoration of the corporate debtor and its creditors to the state each party was in before the case was filed-in other words, the bankruptcy court approximates an "undo" of the bankruptcy case as closely as possible. Dismissal can happen voluntarily or involuntarily (for cause, as discussed above).

\section{E. Sales under 11 U.S.C. $\$ 363$}

The situations described above-Chapter 11 plans of reorganization, Chapter 7 liquidations, and dismissal-involve some final disposition of the bankruptcy case, but corporate debtors have other procedural routes for administering their case before ending it. One important function of the Bankruptcy Code is the debtor-inpossession's ability to sell property of the estate in the middle of the case under section 363 of the Code. ${ }^{51}$ The third subsection, 363(c), allows the debtor to sell property in the ordinary course of business without a separate notice to parties and hearing before the court, while 363(b) sets out the notice-and-hearing requirements for selling estate property outside the ordinary course of business. ${ }^{52}$ Importantly, the latter provision can be used to sell substantially all the debtor's assets outside the ordinary course of business, but a notice and hearing will be required.

\footnotetext{
${ }^{44}$ Id. $\S \S 342,743$. Compare id. $\S 521$ (Debtor's duties), with id. $\S 704$ (Trustee's duties).

${ }^{45} I d . \S 701(\mathrm{a})(1)$.

${ }^{46} I d . \S 702$.

${ }^{47}$ Id. $\$ 726$.

${ }^{48} I d . \S 727(\mathrm{a})$.

${ }^{49} I d . \S 726(\mathrm{a})$.

${ }^{50} I d . \S 349(\mathrm{~b})(3)$.

${ }^{51} I d . \S 363(\mathrm{~b})-(\mathrm{c})$.

${ }^{52}$ Id.
} 
Sales of substantially all assets under section 363(b) can be a very attractive option for corporate debtors looking to sell the company. Section 363(b) does not dictate mandatory terms or list permissive terms like Chapter 11 does for plans of reorganization, nor does it specify the procedure without flexibility like Chapter 7 does for liquidations. At least in theory, the Code allows the corporate debtor to sell any property of the estate - and even, in fact, all property of the estate - provided that the bankruptcy court approves the sale after notice and a hearing. In practice, however, courts apply at least some scrutiny to such sales of substantially all assets and can take objections to a proposed sale seriously. In the Second Circuit Court of Appeals, for example, the court announced a "business justification" test in the seminal Lionel Corp. case: "there must be some articulated business justification, other than appeasement of major creditors, for using, selling, or leasing property out of the ordinary course of business before the bankruptcy judge may order such disposition under section 363(b). ${ }^{.53}$

Based on this Lionel Corp. test, proponents of a sale outside the ordinary course of business under 363(b) must show some business-related reason for the sale-for example, that such a sale is an objectively good deal for the assets to be sold. ${ }^{54}$ This test operates both as a protection for creditors and for the corporate debtor. The creditors are protected from a corporate debtor proposing a sale that significantly disadvantages them in favor of a more persuasive creditor, and the debtor is protected from high-leverage corporate creditors exercising their influence over the estate to force a sale too early. ${ }^{55}$ To illustrate this protection, a situation could arise where a particular creditor has very high priority or is fully secured (or undersecured) in certain property. In any distribution, be it a sale, a reorganization plan, or a liquidation, this creditor will be paid in full before many other creditors are paid at all. This creditor is therefore less worried about preserving the debtor as a going concern or maximizing the value of the estate and more worried about getting paid early, thus minimizing the risk that the debtor in possession commits too much money to other creditors or spends more money on administration of the bankruptcy case. These interests - getting paid early and maximizing the value of the estate - can easily come into conflict, especially if the corporate debtor has a significant chance of reorganizing successfully through a Chapter 11 plan, which could increase recovery to all parties but take years to complete. ${ }^{56}$ In this hypothetical, given an option between, on one hand, a Chapter 11 plan that increases the value of the estate and recovery of all creditors but takes years to complete and involves some risk of underpayment, and, on the other hand, a section 363(b) sale of substantially all assets that does not maximize recovery but allows for earlier and more certain payment of the creditor's claim, this high-leverage creditor would choose the section 363(b) sale. The Lionel Corp. test for 363(b) sales explicitly prevents this creditor's preference from forming the basis for a sale that may not be the best business decision for the corporate debtor but satisfies the interests of an influential creditor.

Section 363 of the Bankruptcy Code also gives corporate debtors an important tool

${ }^{53}$ In re Lionel Corp., 722 F.2d 1063, 1070 (2d Cir. 1983).

${ }^{54} \mathrm{Id}$. at 1071 .

${ }^{55}$ See Debtors and Creditors, supra note 14, at 697-704 (discussing the Lionel standard).

56 See id. at 697 (describing the tradeoff between full Chapter 11 plans and the quicker procedure available through $\S 363$ sales). 
to maximize the value of the estate: selling property of the estate free and clear of liens. ${ }^{57} \mathrm{~A}$ corporation filing for bankruptcy almost always has significant amounts of secured debt, which means that creditors have liens on some property the corporation owns that "secures" repayment of that debt. Because of the high amount of secured debt, much of the property of the estate - at least the property that can easily and profitably be sold - is likely to be encumbered by liens. Property encumbered by liens is less valuable than unencumbered property because, subject to restrictions and protections in state law, the lienholder may have the right to foreclose on the property to collect the value of their claim and will have the right to payment from the proceeds of a sale if the property is sold otherwise. The power to sell property in bankruptcy cases free and clear of liens is, thus, an important tool for maximizing the value of the estate and attracting interested buyers when property of the estate is to be sold.

Section 363(f) sets out the requirements for selling property free and clear of liens and interests. Notably, this section applies to sales under sections 363(b) and 363(c), so it can be used to sell property free and clear of liens whether or not the sale would be in the ordinary course of the corporate debtor's business. ${ }^{58}$ A corporation could use section 363(f) to sell substantially all its assets outside of the ordinary course of business; this is one available avenue that companies can take to use a Chapter 11 bankruptcy case to sell the business. As discussed above, a corporate debtor can also sell its business in bankruptcy through a Chapter 11 Plan $^{59}$ or by Chapter 7 liquidation ${ }^{60}$ but a section 363 sale (be it a 363(c) ordinary-course-of-business sale, a 363(b) non-ordinary-course sale, or a 363(f) sale free and clear of liens and interests) has different requirements and advantages such that a corporate debtor might choose a section 363 sale instead of another bankruptcy-sale method.

\section{JEVIC: WHEN THE ABSOLUTE PRIORITY RULE APPLIES}

The absolute priority rule, discussed above, applies to at least some distributions of estate property in bankruptcy cases: liquidation distributions in Chapter 7 cases and crammed-down plans of reorganization in Chapter 11 cases. ${ }^{61}$ In these distributions, priority creditors must be paid in full on their claims before creditors of lower priority receive any payment on their claims at all. ${ }^{62}$ It remains unclear, however, whether and when the absolute priority rule applies in other circumstances. United States Circuit Courts of Appeals disagree about whether settlements proposed in the middle of a Chapter 11 case - that is, before any plan of reorganization is proposed or confirmed and before conversion to Chapter 7 liquidation or dismissal-must also follow the

\footnotetext{
5711 U.S.C. $\$ 363(f)$ (2019).

${ }^{58} I d$.

${ }^{59}$ See id. § 1123(b) (allowing a plan to include, among other provisions, a sale of substantially all of the debtor's assets and the reduction of claims or liens).

${ }^{60} I d . \S 726$.

${ }^{61}$ Debtors and Creditors, supra note 14, at 641; 11 U.S.C. $\S \S 1129(\mathrm{~b})(2), 726(\mathrm{a})$, 508(a) (2019).

${ }^{62}$ Debtors and Creditors, supra note 14, at 641.
} 
absolute priority rule in distributing funds to creditors. ${ }^{63}$ Just last year, the Supreme Court of the United States decided Czyzewski v. Jevic Holding Corp. ${ }^{64}$ In Jevic, the Supreme Court struck down a structured dismissal of a Chapter 11 case that provided for payment of some low-priority unsecured claims but did not provide for payment of high-priority wage claims of the defunct company's employees. ${ }^{65}$ The settlements in different Circuit Courts that led up to the Jevic case, and the cases applying the ruling in Jevic, shed more light on what this ruling means for corporate debtors reorganizing in the United States.

\section{A. Pre-Plan Settlements Before Jevic}

In addition to the avenues available for a corporate debtor in the United States described above - including Chapter 11 plans of reorganization, Chapter 7 liquidation, and sales under section 363 of the Code-debtors can also enter into settlements related to their bankruptcy case. Bankruptcy courts have discretion to approve settlements and compromises under Rule 9019 of the Federal Rules of Bankruptcy Procedure. ${ }^{66}$ Jurisdiction to approve these settlements comes from section 1334 of the United States Code, Title 28: "the district courts shall have original but not exclusive jurisdiction of all civil proceedings arising under title 11, or arising in or related to cases under title 11," and the district courts then refer bankruptcy cases to bankruptcy courts under section 157 of the same title. ${ }^{67}$

Bankruptcy courts presented with a settlement evaluate the settlement, approve it, and notify the other parties in interest. ${ }^{68}$ Although Rule 9019 itself does not lay out the criteria to be used when evaluating a settlement, bankruptcy courts often draw from the Supreme Court's 1968 decision in TMT Trailer Ferry when evaluating a settlement for approval. ${ }^{69}$ The TMT Trailer Ferry opinion sets out multiple factors for evaluation of litigation settlements, including the probability of success of the litigation to be settled, the costs and complexity of the case, any difficulties that might be encountered in collecting a judgment, and the overall interests of the creditors in seeing the settlement approved. ${ }^{70}$ When deciding whether a settlement is fair and equitable, that standard "incorporates the absolute priority doctrine" such that "participation by junior interests depends upon the claims of senior interests being fully satisfied."

Some courts apply this TMT Trailer Ferry standard for settlement approval to require that every pre-plan settlement must comply with the absolute priority rule.

\footnotetext{
${ }^{63}$ See In re ICL Holding Co., 802 F.3d 547 (3d Cir. 2015); In re Iridium Operating LLC, 478 F.3d 452 (2d Cir. 2007).

${ }^{64} 137$ S. Ct. 973,978 (2017).

${ }^{65} \mathrm{Id}$.

${ }^{66}$ FED. R. BANKR. P. 9019.

6728 U.S.C. $\S \S 1334(b), 157(a)$ (2019).

${ }^{68}$ FED. R. BANKR. P. 9019.

${ }^{69}$ Protective Comm. for Indep. Stockholders of TMT Trailer Ferry, Inc. v. Anderson, 390 U.S. 414 (1968).

${ }^{70} I d$. at 424 .

${ }^{71} I d$. at 441 .
} 
Notably, the Court of Appeals for the Fifth Circuit imposes this standard: "a bankruptcy court abuses its discretion in approving a [pre-plan] settlement with a junior creditor unless the court concludes that priority of payment will be respected as to objecting senior creditors." 72

The Third Circuit, in ICL Holding, examined a settlement that allegedly violated the absolute priority rule in a different light. ${ }^{73}$ In ICL Holding, the debtor sold substantially all of its assets in a credit bid to its secured creditors. ${ }^{74}$ The unsecured creditors' committee and the United States government objected to the sale. ${ }^{75}$ Later, the "[unsecured creditors'] Committee struck a deal with the secured lender group. In exchange for the Committee's promise to drop its objections and support the sale, the secured lenders agreed to deposit $\$ 3.5$ million in trust for the benefit of the general unsecured creditors." 76 Since the estate would be administratively insolvent after the sale - that is, no funds would be left in the estate to pay its expected administrative expense - the U.S. government argued that the settlement funds were proceeds from estate property and, thus, that distribution of those funds to the unsecured creditors' trust would violate the absolute priority rule. ${ }^{77}$

The Third Circuit, however, held that no property of the estate was involved in the settlement, and when no property of the estate is involved, there can be no violation of the absolute priority rule. ${ }^{78}$ The court affirmed the bankruptcy court's finding that "because the settlement monies were paid directly to the unsecured creditors from a trust funded by the purchaser and not given in exchange for any estate property," those funds were not property of the estate. ${ }^{79}$ Further, "the Bankruptcy Code's creditorpayment hierarchy only becomes an issue when distributing estate property." 80 Thus, the Third Circuit upheld a settlement that distributed funds outside of the absolute priority rule, although it is unclear whether it would apply the opposite analysis to a settlement that distributed property of the estate.

The Second Circuit has held, in at least one case, that distribution of property of the estate in a pre-plan settlement need not strictly follow the absolute priority rule. In In re Iridium, the court of appeals examined a settlement that cut out certain creditors. ${ }^{81}$ The Second Circuit explained that a bankruptcy court can "endorse a settlement that does not comply ... . with the priority rule" if the parties to the settlement justify the settlement, and the reviewing court clearly articulates the reasons

${ }^{72}$ United States v. AWECO, Inc. (In re AWECO, Inc.), 725 F.2d 293, 298 (5th Cir. 1984).

${ }^{73}$ In re ICL Holding Co., 802 F.3d 547 (3d Cir. 2015).

${ }^{74} \mathrm{Id}$. at 550.

${ }^{75} I d$. at $550-51$.

${ }^{76} \mathrm{Id}$. at 551 .

77 Id.

${ }^{78} I d$. at 552.

${ }^{79}$ Id. at 555 .

${ }^{80} I d$.

${ }^{81}$ Motorola, Inc. v. Official Comm. of Unsecured Creditors (In re Iridium Operating LLC), 478 F.3d 452 (2d Cir. 2007). 
for approving the settlement. ${ }^{82}$ The Second Circuit upheld the Bankruptcy Court's conclusion that the settlement had a proper business justification and was not an evasion of bankruptcy procedure. ${ }^{83}$

\section{B. The Jevic Case}

The Supreme Court originally granted review in the Jevic case to resolve the apparent split between the Second Circuit ${ }^{84}$ and the Fifth Circuit: ${ }^{85}$ does the absolute priority rule apply just as strictly to pre-plan settlements as it does confirmable plans ${ }^{86}$ Ultimately, the Court ruled on a narrower issue: structured dismissals in Chapter 11 bankruptcy cases cannot be approved if they violate the absolute priority rule. ${ }^{87}$ In 2006, Sun Capital bought Jevic Holding via a leveraged buyout, and Jevic filed for bankruptcy two years later. ${ }^{88}$ Sun sought a structured dismissal of the case that paid some creditors but did not pay employees' WARN Act claims, which had higher priority than some claims that were paid. ${ }^{89}$ The Court held that such a structured dismissal was impermissible because it violated the absolute priority rule, an important and fundamental provision for the functioning of the Bankruptcy Code..$^{90}$

In a confusing section of the opinion, the Court seemed to leave open the possibility for priority-skipping settlements in some cases:

Courts, for example, have approved "first-day" wage orders that allow payment of employees" prepetition wages, "critical vendor" orders that allow payment of essential suppliers' prepetition invoices, and "roll-ups" that allow lenders who continue financing the debtor to be paid first on their prepetition claims. ... In doing so, these courts have usually found that the distributions at issue would "enable a successful reorganization and make even the disfavored creditors better off." . . . By way of contrast, in a structured dismissal like the one ordered below, the priority-violating distribution is attached to a final disposition; it does not preserve the debtor as a going concern; it does not make the disfavored creditors better off; it does not promote the possibility of a confirmable plan; it does not help to restore the status quo ante; and it does not protect reliance interests. In short, we cannot find in the violation of ordinary priority rules that occurred here any

\footnotetext{
${ }^{82}$ Id. at 464-65.

${ }^{83} I d$.

${ }^{84} I d$.

${ }^{85}$ United States v. AWECO, Inc. (In re AWECO, Inc.), 725 F.2d 293, 298 (5th Cir. 1984).

86 Sally McDonald Henry, Remarks at the 36th Annual Jay L. Westbrook Bankruptcy Conference: Looking the Chapter 11 Gift Horse in the Mouth After Jevic, (Nov. 17, 2017); see also Czyzewski v. Jevic Holding Corp., 137 S. Ct. 973, 978 (2017) (Thomas, J., dissenting).

${ }^{87}$ Jevic, 137 S. Ct. at 985.

${ }^{88}$ Id. at 980 .

${ }^{89} \mathrm{Id}$.

${ }^{90} I d$. at $984-85$.
} 
significant offsetting bankruptcy-related justification. ${ }^{91}$

In this section, the Court seems to embrace Iridium's significant-justification test. The list of seemingly benign examples in the beginning of the excerpt shows that the Court may be open to seeing, for example, critical-vendor orders that flout the absolute priority rule. From the holding, as obfuscated in this section, the only point that is clear is that structured dismissals that violate the absolute priority rule are impermissible. ${ }^{92}$

\section{Cases Applying Jevic}

Bankruptcy courts interpreting Jevic's holding have been inconsistent, but most relevant opinions extend its holding beyond the narrow context of priority-skipping structured dismissals. For example, in In re Pioneer Health Services, a Mississippi bankruptcy court struck down a critical vendor order that violated the absolute priority rule, explaining that Jevic commands more scrutiny than a best-interests test. ${ }^{93}$ The bankruptcy court in In re Fryar also extended the Jevic holding to a non-structureddismissal settlement where the hallmarks of the Jevic settlement were presentespecially violation of the absolute priority rule - and said that such a settlement cannot serve a significant Bankruptcy Code-related objective. ${ }^{94}$ In In re Constellation Enterprises, the Delaware bankruptcy court struck down a structured dismissal, not focusing on whether it violated the absolute priority rule but merely holding that Jevic precluded the approval of structured dismissals. ${ }^{95}$

Not all bankruptcy court decisions out of Delaware similarly extend the Jevic holding; however, the court held in the $D B$ Holdings decision that a structured dismissal was permissible because it did not violate the absolute priority rule. ${ }^{96}$ Further, the bankruptcy court upheld a settlement in In re Short Bark Industries even though it violated the absolute priority rule; notably, it was not an end-of-case settlement and served the significant Code-related objective of allowing the debtor to continue as a going concern. ${ }^{97}$ This case is certainly in the minority, though, as most cases interpreting Jevic have focused on its extension of the absolute priority rule and approved pre-plan arrangements only when the requirements of absolute priority are met.

\section{THE UNITED KINGDOM'S INSOLVENCY SYSTEM}

\section{A. Brief History of English Insolvency Law}

The United Kingdom's system for corporate insolvency is among the oldest and

${ }^{91} I d$. at $985-86$ (internal citations omitted).

${ }^{92} I d$. at 986.

${ }^{93}$ In re Pioneer Health Servs., Inc., 570 B.R. 228, 235 (Bankr. S.D. Miss. 2017).

${ }^{94}$ In re Fryar, 570 B.R. 602, 609-10 (Bankr. E.D. Tenn. 2017).

${ }^{95}$ In re Constellation Enters. LLC, 587 B.R. 275, 277-78 (Bankr. D. Del. 2018).

${ }^{96}$ In re DirectBuy Holdings, Inc., No. 16-12435, 2017 Bankr. LEXIS 4489, at*13-14 (Bankr. D. Del. Jan. 10, 2017).

${ }^{97}$ In re Short Bark Industries, Inc., Ch. 7 Case No. 1:17-BK-11502, Adv. No. 17-51228 (Bankr. D. Del. Sept. 11, 2017). 
most advanced bankruptcy systems in the world, with individual bankruptcy law dating back to the middle ages and corporate insolvency existing formally since at least 1844. ${ }^{98}$ The Joint Stock Companies Act 1844 established that corporations are separate legal entities that can raise credit as institutions, and the Companies Winding Up Act 1844 provided a statutory framework for corporate insolvency proceedings. ${ }^{99}$ Throughout the next century, other statutes provided for separate procedures, yielding a "confused tangle of insolvency laws that was both difficult to operate and prone to manipulation by the unscrupulous." 100 The Cork Committee, headed by Kenneth Cork and tasked with molding a unified, comprehensive insolvency scheme that would curtail potential for abuse, issued the Cork Report in June 1982. ${ }^{101}$ This report, and the legislation that followed, led to the current consolidated statute: the Insolvency Act 1986, which consolidated the Insolvency Act 1985 with the insolvency provisions of the Companies Act 1985. ${ }^{102}$

Modern insolvency in the United Kingdom involves an interplay between the Insolvency Act 1986, the Enterprise Act 2002 which modernized administration procedures, and the Companies Act 2006, which, among other things, allows for preinsolvency restructuring through schemes of arrangement. ${ }^{103}$ The following sections discuss administration under the Insolvency Act 1986 and schemes of arrangement under the Companies Act 2006.

\section{B. The Insolvency Act 1986 and Administration}

The United Kingdom's formal restructuring and insolvency statute is the Insolvency Act 1986. ${ }^{104}$ While the Act does not formally define "insolvent," it sets out criteria for determining whether a company can no longer pay its debts: "it has failed to comply with a statutory demand for a debt over $£ 750$; it has failed to satisfy the enforcement of a judgment debt; or the Court is satisfied that the company is unable to pay its debts as they fall due or that its assets are worth less in value than both its contingent and prospective liabilities." 105 Like the American system, British insolvency allows for liquidations (like Chapter 7) and administrations (like plans under Chapter 11 or Chapter 13). ${ }^{106}$

In an administration under the Insolvency Act 1986, the insolvent company

98 Vanessa Finch \& David Milman, Corporate Insolvency Law: Perspectives and PRINCIPLES 9-11 (3d ed. 2017).

${ }^{99} \mathrm{Id}$. at $11-12$.

${ }^{100} I d$. at 12.

${ }^{101} I d$. at $12-13$.

102 Id. at $14-15$.

${ }^{103}$ Id. at 312-21 (discussing the evolution of administrations with the Enterprise Act 2002); Companies Act 2006, c. 3, $\S 895$ (Eng.) (laying the foundation for schemes of arrangement).

104 Field Fisher Waterhouse, An Overview of UK Insolvency Procedures and the Considerations for Banks with an Insolvent Customer, at 2 (Nov. 2011), https://www.fieldfisher.com/media/2480/178750271.pdf.

${ }^{105} I d$. at 2.

106 HAmish Anderson, The Framework OF CORPORATE InSOlvency LAw 84 (2017). 
benefits from a "moratorium" that triggers upon filing for administration. ${ }^{107}$ Like the automatic stay in American bankruptcy proceedings, the moratorium imposes a stop "on the enforcement of most types of claim, secured and unsecured, against the company." 108 Also, like in the automatic-stay context, creditors may seek court approval to lift the moratorium and seize certain secured property or exercise other rights related to their claims. ${ }^{109}$ The moratorium technically moves in two phases: an "interim moratorium" that comes into effect as soon as the petition for administration is filed, and a general moratorium "for the period the company is in administration." 110 The interim moratorium stays in effect either until the case is dismissed or the company enters administration. ${ }^{111}$ Administration generally carries a one-year time limit but may be extended by the court or with the consent of creditors for up to six months. ${ }^{112}$

\section{Company Voluntary Agreements}

A company voluntary agreement (CVA), like a scheme of arrangement, allows companies to negotiate and compromise with creditors without invoking formal insolvency administration. ${ }^{113}$ Using a CVA, companies can "contract out of . . . insolvency rules which would otherwise apply" in an administration or liquidation; this lends more flexibility for restructuring. ${ }^{114}$ Unlike a scheme of arrangement, however, a CVA is a procedure under the Insolvency Act, so it involves different requirements and protections than a scheme of arrangement, which is governed by the Companies Act 2006. ${ }^{115}$ Additionally, a CVA is likely to involve an insolvency lawyer as a "nominee" and anticipate_or coincide with — an active insolvency, whereas schemes of arrangement may not anticipate or involve an administration at all. ${ }^{116}$ Because CVAs differ significantly in substance and procedure from schemes of arrangement, this Article does not discuss them further.

\section{SCHEMES OF ARRANGEMENT}

The United Kingdom's proprietary, flexible restructuring tool, known as a scheme of arrangement, has its origins in English corporate law from more than a century ago. ${ }^{117}$ While the Companies Act 1862 contained some elements, the "first

\footnotetext{
${ }^{107}$ FinCH \& Milman, supra note 98 , at 302.

${ }^{108} I d$.

${ }^{109} I d$. at $302-03$.

${ }^{110} \mathrm{Id}$. at 316.

${ }^{111} \mathrm{Id}$. at $316-17$.

${ }^{112} I d$. at 321 .

${ }^{113}$ ANDERSON, supra note 106, at 84.

${ }^{114} I d$.

${ }^{115} I d$. at $84-85$.

${ }^{116}$ Id. at 94-96.

${ }^{117}$ Id. at 94-97.
} 
recognizable ancestor to the current legislative provisions" governing schemes of arrangement is found in the Joint Stock Companies Act 1870. ${ }^{118}$ Schemes of arrangement predate CVAs and administrations, but they had not been a popular tool for restructuring corporate debt until the last decade or so, popularized in part by companies restructuring in the wake of the global financial crisis. ${ }^{119}$

Schemes of arrangement are increasing in popularity as a method of restructuring a British company's debt without filing for a formal insolvency administration under the Insolvency Act $1986 .{ }^{120}$ Any company that satisfies the jurisdictional requirements of the Insolvency Act 1986 to file for an insolvency administration can form a scheme of arrangement for court recognition. ${ }^{121}$ A company filing a scheme of arrangement for approval must show:

a) there is a sufficient connection with England;

b) there must be a reasonable possibility of there being benefit to those applying for the scheme to be sanctioned; and

c) one or more persons interested in the distribution of the assets of the company must be persons over whom the court can exercise jurisdiction. ${ }^{122}$

The scheme of arrangement is an operation of English law, but because of this permissive jurisdictional standard, companies incorporated in other countries can and do employ schemes of arrangement to restructure their own debts, as discussed in more detail infra. One example is the case of Re Rodenstock $G m b H,{ }^{123}$ in which the corporate debtor's "only real connection to England was the senior lenders' choice of English law and English jurisdiction as governing their lending relationship with the company." 24 In that case, the English High Court allowed Rodenstock GmbH, a German corporation, to approve a scheme of arrangement in England. ${ }^{125}$

\section{A. Scheme of Arrangement Procedure}

The process of proposing and approving a scheme of arrangement can be complicated and expensive, and some perceive them to be a "cumbersome" process,

\footnotetext{
118 Jennifer Payne, Cross-Border Schemes of Arrangement and Forum Shopping, OxFORD Legal Res. PAPER Series, Sept. 9, 2013, at 1 [hereinafter Payne, Cross-Border Schemes of Arrangement and Forum Shopping].

${ }^{119} I d$.

120 Alastair Goldrein, Ready, Willing and Able, but Perhaps Not Always Acceptable: UK Schemes of Arrangement in Europe, 7 PRATT's J. BANKR. L. 113, 113 (2011).

${ }^{121} I d$. at 115.

122 Id. (citing Stocznia Gdanska SA v. Latreefers Inc. (No. 2) [1998] EWHC 1203 (Comm) applied in the context of schemes in Re Drax Holdings Limited [2003] EWHC 2743 (Ch)).

123 [2011] EWHC 1104 (Ch).

${ }^{124}$ Payne, Cross-Border Schemes of Arrangement and Forum Shopping, supra note 118, at 2.

${ }^{125} I d$.
} 
in part because of the extensive court supervision and discretion involved. ${ }^{126}$ The process involves two separate court hearings, punctuated by meetings of the creditors and stakeholders approving the scheme of arrangement; each step has its own legal and logistical challenges and costs. ${ }^{127}$ The corporation, usually through its board, proposes a scheme of arrangement with its creditors or stakeholders and seeks a court order under Companies Act 2006, section 896, calling meetings of the various classes of parties that the scheme involves. ${ }^{128}$ If the court approves the meetings, those meetings are held, and the parties entitled to vote at each meeting will vote to approve the scheme of arrangement. ${ }^{129}$ Once all required meetings are held and each meeting approves the scheme, "the scheme must be sanctioned by the court." 130

Each of these steps represents a distinct hurdle that the proponent of the scheme of arrangement must clear in order to get the scheme approved, and the process, as a whole, generally takes at least six to eight weeks; complicated schemes of arrangement may take much longer. ${ }^{131}$ Despite the significant cost and complexity of the approval process for schemes of arrangement, the popularity of schemes indicates that the benefits outweigh the costs for some applications. ${ }^{132}$ This section discusses the three main procedural steps in the scheme approval process and the substantive implications of each.

\section{The Company Applies to the Court for an Order Summoning Meetings}

To confirm a scheme of arrangement, a company must meet with creditors of different classes. ${ }^{133}$ If a majority of creditors in each class "representing three quarters in value of the creditors (or class of creditors) approves a scheme of arrangement, it is binding irrespective of any contractual restrictions (such as requirements in the loan document)."134 Thus, this process mirrors the American "cramdown"; it binds creditors even if they voted against the scheme of arrangement and even if they are impaired by the scheme. ${ }^{135}$ This makes definition of classes of interest particularly important: if support for a scheme is not unanimous, there could be significant risk that more than $25 \%$ of the value of the claims in a particular class will vote against the scheme, especially if it leaves that class in a worse position. ${ }^{136}$

126 Jennifer Payne, Schemes of Arrangement: Theory, Structure, and Operation 5 (2014) [hereinafter Payne, Schemes of ARrangement: Theory, Structure, AND OperAtion].

${ }^{127} I d$. at $5-6$.

${ }^{128} I d$. at 18 .

${ }^{129} I d$.

${ }^{130} I d$.

${ }^{131} I d$. at 5 .

${ }^{132}$ Malcolm Lombers \& Andy Radford, London's Scheming - The UK Takeover Panel Takes a Flexible Approach to Schemes of Arrangement, 26 InT'L FIN. L. REV. 46, 46 (2007).

${ }^{133}$ Goldrein, supra note 120 , at 114-15.

${ }^{134} I d$. at 114 .

${ }^{135}$ Id.

${ }^{136} I d$. 
The consideration of classes and separate meetings informs the first step of the process: applying to the court for an order calling the meetings. At this stage, the court does not consider whether the scheme of arrangement by its terms is fair or reasonable. ${ }^{137}$ The court's focus is on whether the creditors and shareholders should meet at one or multiple meetings, and if multiple meetings are necessary, how these meetings should be separated. ${ }^{138}$ Note that the court must strike an important balance: if too many separate meetings are convened, dissenters to the scheme have more power to keep the scheme from being approved, but if too few meetings are held, the dissenting minority has less protection. ${ }^{139}$ The recent trend is toward fewer meetings, "away from overzealous distinctions which give minorities strong veto rights." 140

When determining how many meetings should be held, courts focus on "whether the groups in question are really so dissimilar that they cannot consult together."141 This test favors consolidation into fewer classes and focuses on the relevant parties' rights with respect to the corporation, not their interests in seeing the scheme approved or denied. ${ }^{142}$ In some cases, though, if a proposed scheme will treat parties with similar rights differently, the court may determine that the differently treated subgroups meet and vote separately. ${ }^{143}$ A proponent of a scheme, faced with this possibility, should think twice before arranging a scheme that treats several groups of similarly situated creditors differently because a court may find that each group should have its own meeting, significantly increasing the bargaining power of potential dissenting creditors.

At this stage, the proponent of the scheme of arrangement must make significant disclosures, sending an explanatory statement that clarifies the purpose and function of the scheme and how it will affect the creditors. ${ }^{144}$ If the proponent does not make these disclosures, which are meant to give affected parties notice and opportunity to participate in the meetings, "the court will reject a scheme for non-compliance" and make the proponent start the process over. ${ }^{145}$

\section{Class Meetings and Voting}

Once the meetings are called, each meeting must approve the scheme of arrangement in order for the court to sanction it. ${ }^{146}$ A meeting approves the scheme of

137 Jennifer Payne, Schemes of Arrangement, Takeovers and Minority Shareholders Protection, 11 J. CORP. L. STUD. 67, 88 (2011) [hereinafter Payne, Schemes of Arrangement, Takeovers and Minority Shareholders Protection].

${ }^{138} I d$. at $88-90$.

${ }^{139}$ Id. at 90.

${ }^{140} I d$.

${ }^{141} I d$. at 91 .

${ }^{142} I d$. at $91-92$.

${ }^{143} I d$.

144 Payne, Schemes of Arrangement: Theory, Structure, And Operation, supra note 126 , at 33 .

${ }^{145} I d$.

${ }^{146} I d$. at 57. 
arrangement if a majority of the creditors by number, representing $75 \%$ or more of value owed or held, vote in favor of the scheme. ${ }^{147}$ There is no quorum requirement for meetings, and only parties present or represented by proxy count for determining majority and value supermajority. ${ }^{148}$

There are two important effects of this procedure. First, small-value creditors have much less bargaining power than large-value creditors, particularly when fewer, larger meetings are held; and second, potential dissenting creditors may have far more bargaining power if creditors in favor of the scheme do not or cannot show up to the meeting or vote by proxy.

Even more importantly, while all classes must approve a scheme by these margins, if the scheme passes, it will bind even the dissenting creditors to its terms. This is perhaps the most significant benefit of a scheme of arrangement: it can bind dissenting creditors notwithstanding their objections and without a formal insolvency proceeding.

\section{Court Sanctioning}

Once each meeting has approved the scheme of arrangement, the court must sanction it for it to take effect. ${ }^{149}$ The court will make sure the scheme has met the statutory requirements regarding the explanatory statements and the meetings, including the requisite majorities in number and value. ${ }^{150}$ Additionally, the court uses its discretion to make two substantive determinations: whether the majority fairly represented the class and whether a reasonable person would approve the scheme in question. ${ }^{151}$ The first of those two - whether the majority fairly represented the classexamines the interests of the creditors who voted for the scheme. ${ }^{152}$ This calls judges to look at the merits of the scheme and make sure that the majority approving the scheme has not abused its power, and this examination "can operate as an important protection for minority creditors and shareholders." 153 Of all the judicial checks in the scheme approval process, this is the consideration where judges have the most discretion to make sure a scheme is fair.

The second substantive examination - whether a reasonable person would approve the scheme-involves less potential for judicial overhaul of a scheme. According to Professor Payne, the test at this stage "is not 'is this a reasonable scheme?' but rather 'could the class of creditors/members reasonably have approved it?"'154 The court can consider many factors at this stage, including fairness and even the interests of third parties, but "providing the scheme is fair and equitable, the court will not itself judge

\footnotetext{
${ }^{147} I d$.

${ }^{148} I d$.

${ }^{149}$ Payne, Schemes of Arrangement, Takeovers and Minority Shareholders Protection, supra note 137 , at 93 .

${ }^{150} I d$.

${ }^{151}$ Id. at 93-95.

${ }^{152}$ Id. at 94 .

${ }^{153} I d$.

${ }^{154}$ Id. at 95.
} 
its commercial merits." 155 Because of the high-bar application of reasonableness in this examination, it is "extremely rare" that the court will reject a scheme on these grounds. ${ }^{156}$ Thus, the judge's primary exercise of discretion over scheme approval is in its determination of whether the majority fairly represented the class in which it voted, but a scheme that does not satisfy the statutory requirements or that could not have been reasonably approved will be rejected.

\section{B. Substantive Requirements of a Scheme of Arrangement}

Another advantage of schemes of arrangement is their substantive flexibility. The Companies Act 2006 does not impose substantive requirements on schemes of arrangement apart from the definition as a "compromise or arrangement." 157 To fit under the definition of "scheme of arrangement," the scheme must involve some trade of consideration as opposed to mere forfeiture of rights or interests. ${ }^{158}$ Thus, for example, a proposal that unsecured creditors receive nothing would not qualify as a scheme; by contrast, a cancellation of old debt in exchange for new debt guaranteed by a solvent parent company would qualify. ${ }^{159}$ The lack of any rigid structure or unwieldy substantive requirements makes schemes of arrangement an ideal tool for companies looking to rework only part of their capital structure, and it enables corporate debtors to stay in control of the company.

Importantly, though, any scheme of arrangement will still be subject to the judicial checks described above. This lack of substantive statutory requirements and imposition of judicial discretion indicates an impressive amount of trust in judges in the English legal system. The American Bankruptcy Code gives judges many more statutory parameters - and in theory significantly less discretion - than the United Kingdom, at least in the context of schemes of arrangement.

\section{Using a Scheme of Arrangement to Sell the Company}

A scheme of arrangement, when properly executed, can even help a corporation sell itself more effectively or profitably. Solvent schemes of arrangement can be used in the process of mergers and acquisitions to buy and sell companies while simultaneously dealing with the target company's creditors. ${ }^{160}$ Commentators on this process note that "[t]he increasing popularity of schemes in effecting the largest transactions is a reflection of the market's acceptance that the advantages now outweigh the disadvantages." 161 Competing bidders will often combine their offers with pre-packaged schemes of arrangement, hoping that the benefits of the scheme

\footnotetext{
${ }^{155} I d$.

${ }^{156} I d$.

157 Payne, Schemes of ArRangement: Theory, Structure, And Operation, supra note 126 , at 21 .

${ }^{158} I d$.

${ }^{159} I d$.

${ }^{160}$ See generally Malcolm Lombers \& Andy Radford, London's Scheming - The UK Takeover Panel Takes a Flexible Approach to Schemes of Arrangement, 26 INT'L FIN. L. REV. 46 (2007).
}

${ }^{161} I d$. at 46. 
will make their offer more competitive and help their bid get accepted faster. ${ }^{162}$

In her extensive commentary on this subject, Professor Jennifer Payne notes that using a scheme of arrangement to effect a merger or takeover can be an effective way to circumvent some English regulations that usually apply to takeovers. ${ }^{163}$ For instance, takeovers involving an open offer to buy shares will require purchase of $90 \%$ of the target's shares before the minority shareholders can be squeezed out - that is, compelled to sell their shares at the offer price. ${ }^{164}$ In a scheme of arrangement, the dissenting minority can be bound to the terms of the scheme so long as a majority of each class representing $75 \%$ of value vote to approve the scheme. ${ }^{165}$ In theory, therefore, a takeover by scheme of arrangement would allow effective squeeze-out with a lower threshold approving: if the scheme had only one class of shareholders, only $75 \%$ of shares would need to vote in favor to bind the holdouts in the class. ${ }^{166}$ Additionally, selling a company using a scheme of arrangement can save the company taxes so long as capital is not increased in the process. ${ }^{167}$ Both of these reasons contribute to the popularity of schemes of arrangement by solvent companies.

\section{Recognition of Schemes of Arrangement in Other Countries}

While schemes of arrangement can be used to reorganize debts without filing for a formal insolvency administration, a potential drawback is that some countries may not recognize the scheme of arrangement, particularly if it is arranged completely separately from any bankruptcy proceeding. Both European Union regulations and UNCITRAL Model Laws consider "insolvency proceedings" to include only those "premised on the actual or anticipated insolvency of the subject company (as opposed to being proceedings under general laws which may be invoked without any actual or anticipated insolvency - for example schemes of arrangement under the Companies Act 2006)." 168 Some jurisdictions, notably European courts applying EU Regulations, will not consider schemes of arrangement by solvent companies to be "insolvency proceedings" under this definition.

In particular, German courts have held on different occasions that the European Union's agreements about enforcing other countries' judgments do not apply to certain English schemes of arrangement that purport to bind nonconsenting German claimants when no formal insolvency proceeding has been filed. ${ }^{169}$ For instance, in the Equitable Life case in 2009, the German Higher Regional Court held "that the scheme was not a

\footnotetext{
${ }^{162} I d$. at $46-48$.

${ }^{163}$ Payne, Schemes of Arrangement, Takeovers and Minority Shareholders Protection, supra note 137, at 68 .

${ }^{164} I d$.

${ }^{165} I d$.

${ }^{166} I d$.

${ }^{167} I d$. at 70.

168 See ANDERSON, supra note 106, at 17 (discussing the "distinguishing characteristics" of international insolvency proceedings and referring to the overlap between the EU and UNCITRAL definitions).
}

${ }^{169}$ Goldrein, supra note 120 , at 116. 
judgment pursuant to Articles 32 and 33 of Council Regulation No 44/2001 in that it lacked the requisite characteristics of a judgment which necessitated a potential or actual dispute between the parties involved." 170 This decision was upheld in relevant part in 2012 by the German Federal Court of Justice, also noting that the Brussels Regulation's jurisdictional requirements limited the application of schemes of arrangement reorganizing debts of insurance companies. ${ }^{171}$ Arthur Swierczok notes that "Germany has been slow to deal with" schemes of arrangement, based in part on the country's "strict dualistic" conception of insolvency. ${ }^{172}$ Germany does not have an analogous, pseudo-insolvent procedure like a scheme of arrangement, and the prevailing understanding is that "a company is either flourishing, or insolvent." 173

German companies have sought out English schemes of arrangement successfully, albeit without obtaining recognition in Germany. ${ }^{174}$ Problematically, though, if such schemes are not recognized by German courts, they will not be enforceable against dissenting creditors in Germany, who will be free to "disregard the scheme and enforce their claims or other rights against the company." 175 This would render international insolvency using schemes of arrangement virtually unworkable where a significant number of dissenting creditors are in Germany or other European Union jurisdictions that have not extended recognition to schemes of arrangement. Because it does not include an insolvency-style moratorium or automatic stay, a scheme's power lies in its binding force upon approval, and if German creditors are effectively not bound to a scheme of arrangement to which they dissent, the scheme would be ineffective to stop rogue creditors.

Schemes of arrangement have been recognized in Spain ${ }^{176}$ and Singapore, but a Singaporean court recently deciding a scheme of arrangement case disagreed with the Applicant's assignment of claimants to a single class and split the claims into two classes. ${ }^{177}$ As discussed above, the number and status of classes is very important to the proper function of a scheme of arrangement because each class involved in the scheme must approve the scheme by majority vote and the approval of at least $75 \%$ of the class's aggregate claim value. Consequently, a scheme of arrangement is binding on all creditors in a class, regardless of whether or not they approved it and whether or not they were known at the time the scheme was approved. Because of the importance of the number and character of classes involved in a scheme of arrangement, the possibility that a foreign court will accept a scheme of arrangement but reorganize the classes involved could complicate or frustrate the purpose of the scheme.

\footnotetext{
${ }^{170} I d$.

${ }^{171}$ Susan Block-Lieb, Reaching to Restructure Across Borders (Without Over-Reaching), Even After Brexit, 92 AM. BANKR. L.J. 1, 22 (2018).

172 Arthur Swierczok, Recognition of English Solvent Schemes of Arrangement in Germany, 5 King’s Student L. Rev. 78, 78 (2014).

${ }^{173}$ Id. at $78-79$.

${ }^{174} \mathrm{Id}$. at 79.

${ }^{175} I d$.

${ }^{176}$ Goldrein, supra note 120 , at 118 .

${ }^{177} R e$ : Empire Capital Resources Pte Ltd, [2018] SGHC 36 (Singapore).
} 
Part of the problem with European recognition arises from the fact that several different European regulations could govern schemes: the EU Insolvency Regulation, the Brussels Regulation, and the Rome Regulation. ${ }^{178}$ As discussed above, the EU Insolvency Regulation has been held to not apply to schemes of arrangement because it is not an "insolvency proceeding." 179 And while the Brussels Regulation and the Rome Regulation arguably could include schemes of arrangement, neither one has been applied to justify foreign recognition of an English scheme of arrangement. ${ }^{180}$

The United States, by contrast, does recognize English schemes of arrangement through Chapter 15 of the Bankruptcy Code. ${ }^{181}$ An approved scheme of arrangement is a "foreign main proceeding" that can be recognized, as discussed in more detail below. ${ }^{182}$

\section{COMPARING SCHEMES OF ARRANGEMENT TO AMERICAN BANKRUPTCY AFTER JEVIC}

\section{A. Substantive Provisions and the Power to Bind Nonconsenting Creditors}

A key difference between schemes of arrangement and Chapter 11 plans involves the substantive requirements of each. Chapter 11 plans must contain provisions as dictated in section 1123, meet the standards for a confirmable plan in section 1129, and conform to the absolute priority rule in the event of a cramdown. ${ }^{183}$ If all classes entitled to vote approve a Chapter 11 plan, the dissenting creditors will be bound to the terms of the plan as if they had accepted it, and the plan will not be subject to cramdown restrictions. Even if a class does not approve the plan, it can still be bound to the terms of the plan via cramdown, which would institute the absolute priority rule and enable the members of that class to get paid in full on their claims before lowerpriority creditors receive anything.

Schemes, by contrast, have fewer and different substantive requirements. In theory, any "compromise" between the creditors and the debtor can be approved as a scheme of arrangement; in other words, as long as creditors and stakeholders receive some consideration for the postponement or cancellation of their payments, such a scheme can be approved. ${ }^{184}$ Judges exercise discretion in sanctioning schemes of arrangement, but the standards are not nearly as burdensome or mechanical as those of Chapter 11 plans in cramdown. ${ }^{185}$ Schemes of arrangement, for instance, do not

\footnotetext{
${ }^{178}$ Block-Lieb, supra note 171, at 18.
}

${ }^{179} I d$.

${ }^{180} I d$. at $19-21$.

181 See In re Avanti Comms. Group PLC, 582 B.R. 603, 613 (Bankr. S.D.N.Y. 2018) (collecting cases from multiple bankruptcy courts that recognized schemes of arrangements as foreign main proceedings).

${ }^{182}$ Id. at 614; see infra Part V, Section D.

18311 U.S.C. $§ 1129(b)(2)(2019)$.

184 Payne, Schemes of Arrangement: Theory, Structure, and Operation, supra note 126 , at 21 .

${ }^{185} \mathrm{Id}$. at $20-23$. 
have an absolute priority rule or any other superimposed hierarchy of payment apart from common-law priority. Importantly, though, schemes must be approved by all classes entitled to vote, whereas Chapter 11 plans in cramdown can theoretically have all but one class of creditors reject the plan overall and still be binding on dissenting creditors.

As discussed above, Jevic stands for the imposition of the absolute priority rule on settlements proposed before or without a confirmable plan - at least in the context of structured dismissals and probably in other pre-plan contexts. This decision does not impose other substantive requirements of a plan, such as the permissive and mandatory provisions from section 1123, on pre-plan settlements. It seems that the factors for evaluating a settlement, as expressed in TMT Trailer Ferry and its progeny, are the main substantive guidance for pre-plan settlements. ${ }^{186}$ In theory, a "compromise or settlement" under Rule 9019 can be any agreement between two or more parties subject to the bankruptcy court's jurisdiction, and its operation would be subject to contract law primarily, as informed by guidelines from bankruptcy-focused decisions like TMT Trailer Ferry and Jevic. ${ }^{187}$

Despite this substantive flexibility, however, because such settlements are grounded in contract law, they would not bind creditors or claimants that are not parties to the settlement; the settlement would only bind those parties who agree to be bound. The issue in Jevic was not that the structured dismissal would bind the nonconsenting priority creditors to the dismissal; they would not be parties to the settlement. Instead, the structured dismissal in Jevic would have ended the bankruptcy case to which they were a party, settling and paying some claims but leaving the priority claims unpaid and intact. ${ }^{188}$ This arrangement would restore the priority claimants' rights outside of bankruptcy to seek repayment of their claims, but, in practice, it would prevent them from recovering at all: all the insolvent company's value would be funneled to other creditors, leaving them with only an empty pocket from which to seek recovery. So, while the structured dismissal in Jevic did not contractually bind the priority creditors to accept nonpayment or discharge of their claims, the practical effect was to leave them in the cold without any chance to recover before the debtor went under.

Unlike pre-plan settlements, schemes of arrangement bind the nonconsenting creditors upon approval of the scheme. While schemes of arrangement do require consent of most creditors and approval by the court, nonconsenting creditors with lowvalue claims have little power to prevent a scheme from binding them, aside from voting against the scheme. Schemes thus combine the main advantage of Chapter 11 plans - the power to bind nonconsenting creditors - with the flexibility of an open contract, subject to minimal substantive restrictions.

\section{B. Approval and Voting}

A scheme of arrangement, as mentioned above, must be approved by all classes entitled to vote in a meeting. A meeting approves a scheme if a majority in number, representing $75 \%$ in value, vote to approve. A Chapter 11 plan allows impaired classes

186 Protective Comm. For Indep. Stockholders of TMT Trailer Ferry, Inc. v. Anderson, 390 U.S. 414, 453-54 (1968).

${ }^{187}$ Id.; Czyzewski v. Jevic Holding Corp., 137 S. Ct. 973, 978 (2017).

188 Jevic, 137 S. Ct. at 986. 
to vote on the plan, and a class approves the plan if a majority in number, representing two-thirds of value, vote to approve. Even if not all classes approve a Chapter 11 plan, the dissenting classes can still be bound to the terms of the plan via cramdown if the plan conforms to the absolute priority rule. Procedurally, as well as mathematically, a Chapter 11 plan is easier to approve-at least in theory-than a scheme of arrangement.

Importantly, though, a Chapter 11 plan necessarily covers all of a corporate debtor's creditors while a scheme of arrangement may only include some creditors. A corporate debtor could use a scheme of arrangement to restructure only high-leverage or high-priority debts without worrying about formulating the plan carefully around the approval of low-value or low-priority creditors. This added flexibility mitigates the disadvantage of the requirement that all classes approve the scheme of arrangement because the debtor can negotiate with each class separately, although this procedure would not address the risk that a creditor not included in the scheme could exercise its rights against the debtor's assets and frustrate the purpose of the scheme.

\section{Recognition}

Schemes of arrangement face significant problems with recognition in some countries, as discussed in more detail above, but cases filed in the United States may have even more difficulty. The United States does not benefit from any of the jurisdictional treaties of the European Union, and it is not a "relevant country" under the United Kingdom's main recognition statute. ${ }^{189}$ Most countries other than the United States are more territorial about recognition than the European Union, making recognition the exception rather than the rule. ${ }^{190}$

Coming from the other direction, however, courts in the United States will recognize a scheme of arrangement as a "foreign main proceeding" under Chapter 15, allowing application of the automatic stay and other central Bankruptcy Code features to a scheme of arrangement, assuming the satisfaction of Chapter 15's other requirements. ${ }^{191}$ Furthermore, while a corporate debtor seeking recognition of a scheme of arrangement under Chapter 15 must have its domicile, place of business, or property in the United States, the corporate debtor can satisfy this condition by simply depositing funds with a United States law firm as a retainer for legal services. ${ }^{192}$ These cases, however, recognize schemes of arrangement that had already been approved by courts in the United Kingdom, so it remains unclear whether Chapter 15 would apply to schemes of arrangement that have yet to be approved. ${ }^{193}$ In addition, although United States bankruptcy courts tend to be willing to recognize schemes of arrangement, the same scheme may not be so easily recognized or enforced in other

${ }^{189}$ Debtors and Creditors, supra note 14, at 908.

${ }^{190} \mathrm{Id}$. at $908-09$.

191 See In re Avanti Comms. Grp. PLC, 582 B.R. 603, 612-14 (Bankr. S.D.N.Y 2018) (collecting cases from multiple bankruptcy courts that recognized schemes of arrangements as foreign main proceedings for purposes of enforcing the schemes by American court order under Chapter 15).

${ }^{192} I d$. at 613.

193 See id. 
countries - particularly in Europe - as discussed in more detail above. ${ }^{194}$ In any event, the head-to-head comparison favors the United Kingdom's scheme of arrangement, if only because the United States recognizes it under Chapter 15 and the United Kingdom does not recognize judgments in United States Bankruptcy Court under its closest analogue. ${ }^{195}$

\section{Anti-Enforcement Protection}

In a case filed under Chapter 11, the automatic stay of section 362 is an injunction effective upon filing. ${ }^{196}$ It protects the corporate debtor from creditors repossessing or otherwise exercising their rights on their claims, and it remains in force throughout the bankruptcy case. ${ }^{197}$ One of the main disadvantages of a scheme of arrangement is that there is no such automatic stay, and the moratorium that applies to administrations is also unavailable. ${ }^{198}$ This means that, until final approval of the scheme of arrangement, "each individual creditor is thus able to exercise all the rights and remedies that he or she possesses against the company debtor." 199 This "period of high vulnerability" is estimated to last at least eight weeks, and complicated or contentious schemes may take longer, leaving the debtor open to possible involuntary administration, repossession of assets, or continuation of lawsuits. ${ }^{200}$

The fact that anti-enforcement protection is available in United States bankruptcy proceedings and unavailable in a scheme of arrangement is perhaps the strongest point in favor of the United States in this comparison. A scheme of arrangement, as discussed above, requires extensive disclosures at the outset, and these disclosures would signal to potential dissenting creditors that the corporate debtor (1) will be unprotected from creditor action for about two months and (2) may change or even cancel their claims, notwithstanding their objections, after those two months. This presents the danger of backlash before the scheme of arrangement can be approved, possibly even preempting the scheme's approval entirely, depending on how the potential dissenting creditors react. It is important, though, not to overstate this danger: in practice, a corporate debtor can couple the scheme of arrangement with an administration filing, which would put a moratorium in place while the scheme's proponents seek approval. ${ }^{201}$ This practice still requires a formal insolvency filing, though, so it offers cold comfort to a corporation that seeks to restructure some of its debts while avoiding formal administration.

Essentially, a corporation choosing English law to restructure must choose between avoiding formal insolvency filings and receiving moratorium protection; it

\footnotetext{
${ }^{194}$ See supra Part IV, Section D.

195 Debtors and Creditors, supra note 14, at 908.

19611 U.S.C. § 362(a) (2019).

${ }^{197} I d$.

${ }^{198}$ Finch \& MiLman, supra note 98, at 414.

${ }^{199} I d$.

${ }^{200} \mathrm{Id}$. at $414-15$.

${ }^{201} I d$. at 415.
} 
cannot have both. ${ }^{202}$ Of course, American bankruptcy allows the imposition of the automatic stay regardless of which Chapter the corporation uses to file, and because there is no informal-proceeding option, corporations filing in America choose moratorium protection by default. Chapter 15 recognition of a scheme of arrangement seems at first blush like a viable workaround, because bankruptcy courts in the United States recognize approved English schemes as "foreign main proceedings." ${ }^{203}$ But in those cases, the schemes of arrangement to be recognized had already been approved, so it is unclear if U.S. bankruptcy courts would extend that precedent to schemes that have not yet been approved. Even if American courts extended current precedent to cover not-yet-approved schemes of arrangement, the scheme might not be recognized quickly enough to prevent creditors from exercising their rights, and the automatic stay would not necessarily apply to creditors entirely outside of the U.S. courts' jurisdiction.

\section{CONCLUSION}

The question persists: why would a corporation file for bankruptcy if it is solvent? Solvency is not exactly binary, and corporations headed toward insolvency have myriad incentives to avoid crossing that line - if indeed the line exists. Bankruptcy is an expensive and often stigmatized process, and it can hurt a company's creditworthiness and goodwill on top of the significant legal fees required. Yet it creates significant value for the corporate filer through a collective process that allows companies to restructure their debts without hemorrhaging value, essentially changing the terms of all their debt contracts at once. The United Kingdom's scheme of arrangement allows companies to restructure some of their debts when forced into a tight spot, avoiding all-out insolvency and the costs and stigma associated with itfor example, by focusing on high-leverage or high-pressure creditors. This system is an avenue to fix a financial problem before it spreads; if formal insolvency is fire insurance, the United Kingdom's scheme of arrangement is a fire extinguisher. A distressed (but not yet doomed) corporation would be remiss not to use the latter if it is available and necessary.

\footnotetext{
${ }^{202}$ In the small business context, a corporation might be able to use a CVA that gives limited moratorium protection. See ANDERSON, supra note 107, at 88-89. It is unclear how useful, if at all, this application would be to a multinational corporation or even a large English corporation, and that question is beyond the scope of this Article.

${ }^{203}$ See In re Avanti Comms. Grp. PLC, 582 B.R. 603, 613 (Bankr. S.D.N.Y 2018) (collecting cases from multiple bankruptcy courts that recognized schemes of arrangements as foreign main proceedings); see also 11 U.S.C. § 1520(a) (2019) (extending the protection of the automatic stay under $\S 362$ to foreign proceedings once recognized).
} 